\title{
大殿筋および股関節外旋筋群への静的ストレッチングは しゃがみこみ動作に影響を及ぼすか
}

\author{
Effect of Static Stretching of the Gluteus Maximus and \\ Hip External Rotators on Squat Performance
}

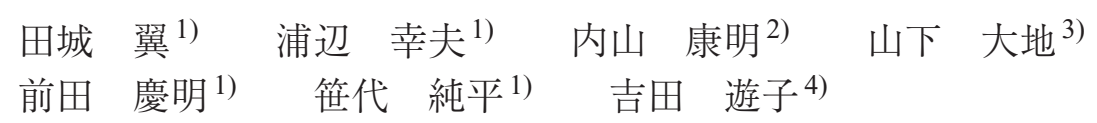

TsUbasa TASHIRO, RPT ${ }^{1)}$, YUKIO URABE, RPT, PhD ${ }^{1)}$, KOMEI UCHIYAMA, RPT ${ }^{2)}$, DAICHI YAMASHITA, RPT ${ }^{3)}$, Noriaki MAEDA, RPT, $\mathrm{PhD}^{1)}$, JunPei SASADAI, RPT, $\mathrm{PhD}^{1)}$, YuKo YOSHIDA, RPT ${ }^{4)}$

1) Graduate School of Biomedical \& Health Sciences, Hiroshima University: 1-2-3 Kasumi, Minami-ku, Hiroshima-shi, Hiroshima 734-8553, Japan TEL+8182-257-5405 E-mail: tsubasatashiro716@hiroshima-u.ac.jp

${ }^{2)}$ Department of Rehabilitation, Saiseikai Karatsu Hospital

${ }^{3)}$ Department of Rehabilitation, Hagiwara Central Hospital

4) Faculty of Rehabilitation, Kyushu Nutrition Welfare University

Rigakuryoho Kagaku 33(6): 935-940, 2018. Submitted Jun. 18, 2018. Accepted Aug. 1, 2018

\begin{abstract}
Purpose] To examine the effect of static stretching of the gluteus maximus and hip external rotators on squat performance. [Participants and Methods] A total of 26 healthy university students with difficulty in performing full-depth squat were divided into 2 groups: stretching the gluteus maximus (SGM, 13); and stretching the hip external rotators (SER, 13). Both groups previously performed self-stretching for 1 week. On measurement, their hip flexion angles when squatting and when resting, in addition to their finger-floor and interbody distances, were calculated. [Results] After intervention, 3 SGM and 9 SER group members became able to perform full-depth squat. The increase in the hip flexion angle when squatting was more marked in the SER compared with SGM group. [Conclusion] SER may be more effective than SGM to become able to perform full-depth squat.
\end{abstract}

Key words: full-depth squat, stretching, hip flexion angle

要旨：〔目的〕大殿筋および股関節外旋筋群への静的ストレッチングがしゃがみこみ動作に及ぼす影響を検証した. 〔対象と方法〕対象はしゃがみこみ動作が不可能な健常大学生 26 名として, 大殿筋のストレッチングをする群（SGM 群）13名と, 股関節外旋筋群のストレッチングをする群（SER 群）13 名に分けた。セルフストレッチングを各群で 1 週間実施し，しゃがみこみ動作時の股関節屈曲角度，安静時股関節屈曲角度，指床間距離，椎体間距離を測定した。 〔結果〕介入後, しゃがみこみ動作が可能となった者はSGM 群 3 名, SER 群 9 名であった. SER 群は, SGM 群と 比較して，しゃがみこみ動作時の股関節屈曲角度が有意に増加した。〔結語〕SERは，SGMに比べてしゃがみこみ 動作の獲得に効果が期待できることが示された.

キ一ワード：しゃがみこみ動作, ストレッチング, 股関節屈曲角度

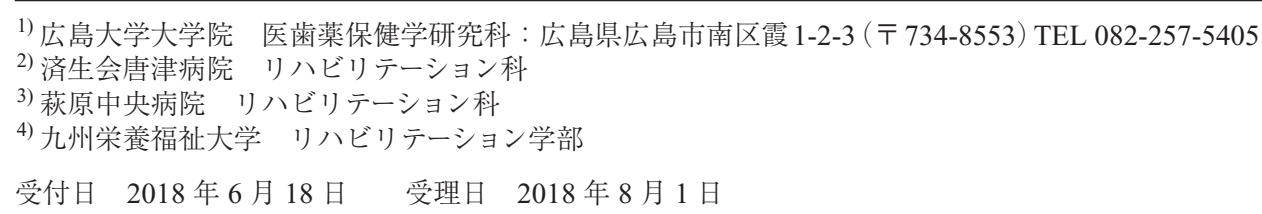




\section{I.はじめに}

しゃがみこみ動作（full squatting motion）は，股関節 屈曲, 膝関節屈曲, 足関節背屈運動を最終可動域近くま で行う必要がある。平成 28 年度から, 全国の小中学校 および高等学校で行われる運動器検診で, 下肢の柔軟性 を評価するチェック項目の一つとして用いられてい $3^{11}$. 平成 19 年度から平成 27 年度にかけて, 小中学生 54000 人を対象として実施された運動器検診では, 全体 の約 $10 \%$ の览童拉よび生徒がしゃがみこみ動作が不可 能であったとされ, 若年者の将来的な運動器症候群が懸 念されている2)。また，野球抒よびサッカー選手を対象 とした研究では，しゃがみこみ動作が不可能な選手は可 能な選手と比較して, 下肢の障害発生率が高かったとし ており、しゃがみこみ動作とスポーツ障害に関係がある ことが示されている ${ }^{3)}$ 。これらのことから，しゃがみこ み動作を可能にすることは, 下肢の柔軟性の低下によっ て引き起こされる様々な障害を予防するという面から重 要な課題であると考えられる。

しゃがみこみ動作の不可能な者（以下，不可能者）は， しゃがみこみ動作の可能な者（以下，可能者）と比較し て, しゃがみこみ動作時の足関節背屈角度が低值である といわれている4)。しかし，しゃがみこみ動作時の足関 節背屈角度を $10^{\circ}$ 以上有する者のなかに可能者と不可能 者が混在し, 不可能者は腰椎屈曲角度には差を認めな かったものの，指床間距離（Finger Floor Distance：以下 FFD）と，しゃがみこみ動作時の骨盤の後方偏移最大值 で有意な差が認められたとされている5)。このことは, しゃがみこみ動作を獲得するための因子として, 体幹屈 曲可動域や足関節背屈可動域以外に股関節屈曲可動域も 関与している可能性があることを示唆している。つまり しゃがみこみ動作の獲得には, 股関節屈曲可動域にも焦 点を当てる必要があると考えられるが, 股関節屈曲可動 域を改善させるための介入が, しゃがみこみ動作に及ぼ す影響は不明である。

股関節屈曲位では, 股関節伸展作用のある大殿筋は, 他動的に引き伸ばされ，伸張されている状態になる6). 一方で, 股関節外旋筋群も, 股関節外旋作用の他に股関 節伸展作用があり，股関節屈曲により伸張位になるとさ

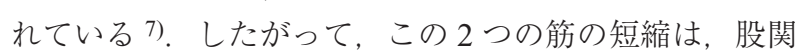
節屈曲運動の制限因子として予想されるため, これらに 対するストレッチングは股関節屈曲可動域を増加させる と考えられる。

本研究の目的は，しゃがみこみ動作時の足関節背屈角 度は $10^{\circ}$ 以上あるが, しゃがみこみ動作が不可能な者に 対して, 股関節屈曲可動域の増加を目的とした大殿筋お よび股関節外旋筋群へのストレッチングがしゃがみこみ 動作に及ぼす影響を確認することとした，仮説は，股関 節屈曲可動域が増加した場合，しゃがみこみ動作が可能
となるとした

\section{II. 対象と方法}

\section{1. 対象}

対象は, 不可能者のうち, しゃがみこみ動作時の足関 節背屈角度が $10^{\circ}$ 以上の健常大学生で, 男性 17 名 (年 齢 $19.8 \pm 1.3$ 歳, 身長 $172.0 \pm 6.1 \mathrm{~cm}$, 体重 $65.8 \pm 8.3$ $\mathrm{kg}$, BMI $22.3 \pm 2.4 \mathrm{~kg} / \mathrm{m}^{2}$ : 平均 \pm 標準偏差) と女性 9 名（年齢 $20.2 \pm 1.0$ 歳, 身長 $155.9 \pm 3.3 \mathrm{~cm}$, 体重 $50.3 \pm 7.6 \mathrm{~kg}$, BMI $20.7 \pm 2.7 \mathrm{~kg} / \mathrm{m}^{2}:$ 平均 \pm 標準偏 差)の計 26 名とした.

対象を，性別を基準とした層別ランダム化により，大 殿筋のストレッチング (Stretching of the Gluteus Maximus：以下, SGM) をする群 (以下, SGM 群) 13 名（男性 8 名，女性 5 名，年齢 $19.8 \pm 1.0$ 歳，身長 $167.4 \pm 10.0 \mathrm{~cm}$, 体重 $60.4 \pm 10.4 \mathrm{~kg}$, BMI $21.4 \pm 2.2$ $\mathrm{kg} / \mathrm{m}^{2}$ : 平均 \pm 標準偏差) と股関節外旋笳群のストレッ チング (Stretching of the Hip External Rotator Muscles : 以下, SER）をする群（以下, SER 群）13名（男性 9 名, 女性 4 名, 年齢 $19.8 \pm 1.2$ 歳, 身長 $165.1 \pm 8.6 \mathrm{~cm}$, 体重 $60.3 \pm 11.3 \mathrm{~kg}$, BMI $21.9 \pm 3.0 \mathrm{~kg} / \mathrm{m}^{2}$ : 平均 \pm 標準偏差）に無作為に分けた。

本研究は、ヘルシンキ宣言に基づき, 研究の目的拉よ び研究方法を十分に説明し, 書面にて同意を得られたも のを対象とした。

\section{2. 方法}

ストレッチング方法は, 対象自身によるセルフスト レッチングで, 種類は静的ストレッチングとした。強度 は, 対象自身が, 筋の伸張により疼痛を感じる直前とし た。 SGM は, 背臥位で左股関節屈曲, 内転, 膝関節屈 曲し，右上肢で左膝窩を把持して，頭側へ引きあげる方 法（図 1 上）とした.SERは，背臥位で右股関節，膝 関節を屈曲，左股関節を開排し左足部を右大腿前部に乗 せ，右膝関節を頭側へ引きあげる方法（図1下）で行い， どちらのストレッチングも左右両側で実施させた。これ らのストレッチングを対象に個別に指導し, 左右それぞ れ 30 秒 8$) \times 5$ 回（1 回ごとに休㮩 30 秒）を 1 日 1 回, 1 週間の計 7 回を実施させた。対象に自己チェック表を 配布し，ストレッチング実施の有無を記入するように指 示した.

ストレッチング前後の測定項目は, SGM 抢よびSER の効果の指標として, しゃがみこみ動作時の股関節屈曲 角度, 安静時股関節屈曲角度, FFD を測定した。 また, SGM およびSER による腰背部筋への影響の有無を確認 するために，椎体間距離を測定した．

しゃがみこみ動作は, 静止立位から開始し, 股関節屈 曲, 膝関節屈曲, 足関節背屈の最終可動域での, 姿勢保 


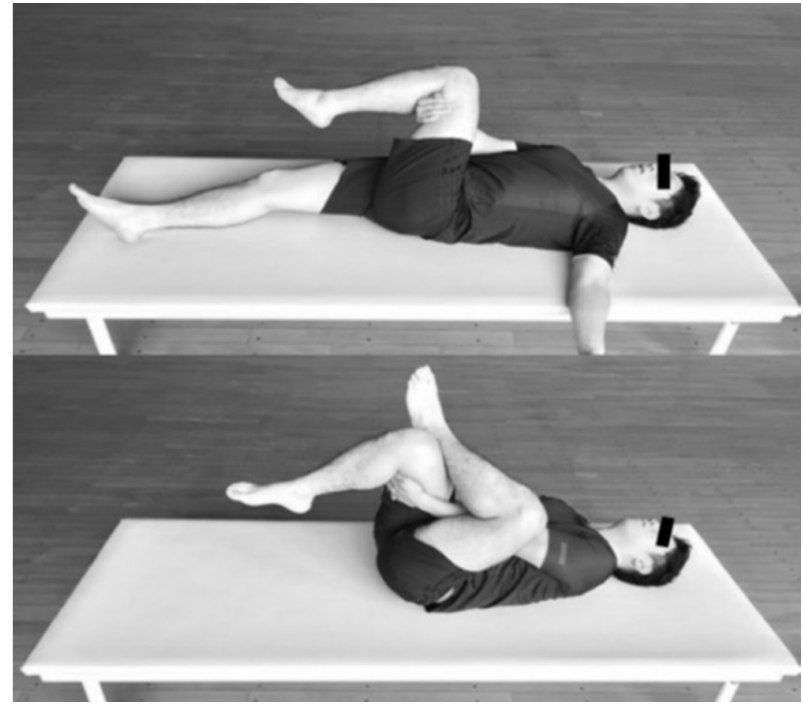

図1 左側ストレッチングの例 (上：SGM，下：SER)

SGM (Stretching of the Gluteus Maximus) の方法は, 背 臥位で左股関節屈曲, 内転, 膝関節屈曲し, 右上肢で 左膝窩を把持して頭側へ引きあげる.

SER (Stretching of the Hip External Rotator Muscles) の 方法は, 背臥位で右股関節, 膝関節を屈曲, 左股関節 を開排し左足部を右大腿前部に乗せ，右膝関節を頭側 へ引きあげる。

持の可否を判定した。しゃがみこみ動作の開始肢位は, 両肩関節 $90^{\circ}$ 屈曲位, 时関節完全伸展位とし, 両膝関節 内側および足関節内側をそれぞれ接触させた肢位と規定 した。開始肢位からゆっくりとしゃがみこみ動作を行い, 踵部を離床せず，20 秒間姿勢保持できた者を可能者, 保持できなかった者を不可能者とした（図 2).しゃが みこみ動作時の股関節屈曲角度の測定は, 肩峰, 大転子, 膝関節裂隙にマーカーを貼付し, 矢状面からしゃがみこ み動作の最終域での姿勢をデジタルカメラ（Fine Pix S 8400, FUJI-FILM 社製）を用いて撮影した。画像分析 ソフト（ImageJ, アメリカ国立衛生研究所）を使用し, 撮影した写真上で肩峰 - 大転子 - 膝関節裂隙のなす角か ら，しゃがみこみ動作時の股関節屈曲角度を測定した。

安静時股関節屈曲角度は, 日本リハビリテーション医 学会および日本整形外科学会が提唱する「関節可動域表 示ならびに測定法」に準じ9), 同一検者が東大式角度計 （TTM-KO，酒井医療社製）を用いて測定した。 FFDは, 安静時股関節屈曲角度と同様の測定法により9)，指先が 床面に達していない場合はマイナスで表記した，椎体間 距離は, テープメジャーを用い, 第 7 頸椎棘突起一第 5 腰椎棘突起間の距離を測定した。FFD 時の測定值から静 止立位時の測定值を引いた值を, 椎体間距離の差とした。

統計解析には, SPSS ver.23.0 J for Windows（IBM 社 製）を用いた。介入前における群間の各測定項目のベー スラインを比較するため, 対応のない $\mathrm{t}$ 検定を行った. 測定項目ごとに，介入方法（2 種類のストレッチング方

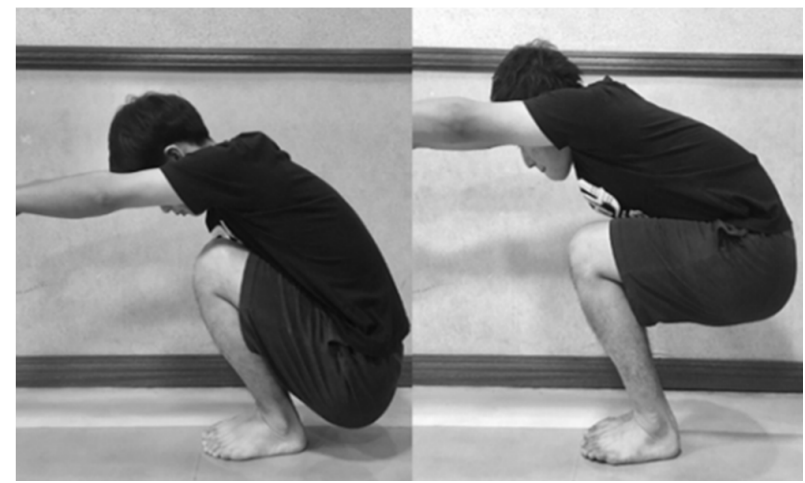

図2しゃがみこみ動作の例 (左：可能者, 右：不可能者) しゃがみこみ動作の開始肢位は, 両肩関節 $90^{\circ}$ 屈曲位, 肘関節完全伸展位とし，両膝関節内側および足関節内 側をそれぞれ接触させた肢位と規定した。開始肢位か らゆっくりとしゃがみこみ動作を行い, 踵部を離床せず, 股関節屈曲, 膝関節屈曲, 足関節背屈の最終可動域で, 20 秒間姿勢保持できた者を可能者，保持できなかった 者を不可能者とした.

法）と測定時期（介入前・後）の二要因による二元配置 分散分析を行った。交互作用が認められた測定項目につ いては，介入方法の違いを比較するために，群間の介入 後の值で対応のない $\mathrm{t}$ 検定を実施した。群別と男女別の しゃがみこみ動作の可否の検討には, Pearsonの $\chi^{2}$ 検定 を用いた。なお，有意水準は $5 \%$ とした。

\section{III. 結 果}

各測定值の結果を表 1 に示した。 1 週間のセルフスト レッチングの実施回数は, SGM 群 $6.2 \pm 1.0$ 回, SER 群 $6.5 \pm 1.0$ 回で, 群間に有意な差は認められなかった。 ベースラインにおける各測定項目はいずれも, 群間で有 意な差を認めなかった。しゃがみこみ動作時股関節屈曲 角度, 安静時股関節屈曲角度, $\mathrm{FFD}$, 椎体間距離の差は, 測定時期に主効果を認めた。また，しゃがみこみ動作時 股関節屈曲角度では，交互作用を認めた。ささらに，介入 後のしゃがみこみ動作時股関節屈曲角度は, SGM 群 $150.2 \pm 9.0^{\circ}$, SER 群 $158.0 \pm 6.0^{\circ}$ であり, SER 群が 有意に高值を示した。

群別のしゃがみこみ動作の可否を表 2 に示した。可能 者は 26 名中 12 名 (SGM 群 13 名中 3 名, SER 群 13 名 中 9 名), 不可能者は 26 名中 14 名 (SGM 群 13 名中 10 名, SER 群 13 名中 4 名）であった. SER 群は介入後, 可能者数が不可能者よりも有意に多かった.

男女別のしゃがみこみ動作の可否を表 3 に示した。可 能者は男性 17 名中 9 名 (SGM 群 2 名, SER 群 7 名), 女性 9 名中 3 名（SGM 群 1 名, SER 群 2 名）であった. 男女間で, 可能者数に有意な差は認められなかった。 
表 1 群間での介入前後の各測定值の比較

\begin{tabular}{|c|c|c|c|c|c|c|c|c|c|}
\hline & \multirow{2}{*}{$\begin{array}{l}\text { 実施回数 } \\
\text { (回) }\end{array}$} & \multicolumn{2}{|c|}{$\begin{array}{c}\text { しゃがみこみ動作時 } \\
\text { 股関節屈曲角度 }\left({ }^{\circ}\right) * \dagger\end{array}$} & \multicolumn{2}{|c|}{$\begin{array}{c}\text { 安静時股関節屈曲角度 } \\
\left({ }^{\circ}\right) *\end{array}$} & \multicolumn{2}{|c|}{ FFD $(\mathrm{cm}) *$} & \multicolumn{2}{|c|}{$\begin{array}{c}\text { 椎体間距離の差 } \\
(\mathrm{cm}) *\end{array}$} \\
\hline & & 介入前 & 介入後 & 介入前 & 介入後 & & 介入後 & 介入前 & 介入後 \\
\hline SC & $.2 \pm 1.0$ & $44.3 \pm 12.3$ & $150.2 \pm 9.0$ & $31.2 \pm 6.2$ & $35.0 \pm 4.3$ & $-4.1 \pm 9.1$ & $2.6 \pm$ & $8.4 \pm 2.0$ & $10.8 \pm 3.6$ \\
\hline SER 群 & $6.5 \pm 6.7$ & $142.9 \pm 14.3$ & $158.0 \pm 6.0$ & $131.9 \pm 7.5$ & $139.2 \pm 5.3$ & $0.5 \pm 6.7$ & $7.4 \pm 5.9$ & $8.2 \pm 2.4$ & $9.0 \pm 2.3$ \\
\hline
\end{tabular}

平均值 \pm 標準偏差. $*$ : 測定時期の主効果 $(\mathrm{p}<0.05), \dagger$ : 交互作用 $(\mathrm{p}<0.05)$. SGM : Stretching of the Gluteus Maximus, SER : Stretching of the Hip External Rotator Muscles, FFD : Finger Floor Distance.

表 2 介入後の群間でのしゃがみこみ動作の可否の分布

\begin{tabular}{lccc}
\hline & 可能者数 (\%) & 不可能者数 (\%) & $\mathrm{p}$ 值 \\
\hline SGM 群 & $3(23.1)$ & $10(76.9)$ & 0.018 \\
SER 群 & $9(69.2)$ & $4(30.8)$ & \\
\hline
\end{tabular}

\section{IV. 考 察}

本研究の目的である股関節屈曲可動域を増加させるた めのストレッチングがしゃがみこみ動作へ及ぼす影響に ついて述べる。本研究の結果から, 筆者らの仮説のよう に, 股関節屈曲可動域の増加によってしゃがみこみ動作 は可能となったことが確認できた，対象は，規定のセル フストレッチングを全員実施できた。しかし，しゃがみ こみ動作が可能となった者は, 全対象 26 名中 12 名であっ たことから，1 週間という介入期間ではしゃがみこみ動 作におよぼす効果が不十分であったことが考えられた。

しゃがみこみ動作時の股関節屈曲角度は, 主効果と交 互作用を認め, SER 群が SGM 群に比べて, 介入後に高 值を示した，股関節外旋筋群のなかでも，梨状筋は仙骨 前面から大転子先端の後縁, 内閉鎖筋は骨盤内面の閉鎖 孔周囲から大転子の転子窩に付着している ${ }^{10)}$. 筋の走 行から, これらの 2 筋は, 股関節外旋作用に加えて股関 節伸展作用も有するとされている11). 先行研究では, 股関節屈曲時に, 大殿筋の伸張はわずかであったことに 対して, 股関節外旋筋群は強く伸張され, 特に梨状筋と 内閉鎖筋の短縮は，股関節屈曲の大きな制限因子となる としている 11)。また, 梨状筋は, 股関節屈曲角度によっ て作用が異なる筋である 12)。股関節最大屈曲位では, 股関節内旋作用をもち，股関節外旋方向への制限因子と なっていた可能性も考えられる。 よって, 大殿筋よりも 股関節外旋筋群の方が, 股関節屈曲を制限する可能性が 高いことが予測された。そのため, SERはSGM と比較 して, 股関節屈曲可動域の増加に強く関与することが考 えられ，しゃがみこみ動作時の股関節屈曲角度を増加さ せるストレッチング効果が高いと推察した。

ストレッチング効果の指標の一つである FFDは，測 定時期に主効果を認めたものの, 交互作用は認められな かったＦFDに影響を及ぼす因子として，腰背部筋と
ハムストリングの伸張性, 骨盤前傾角度が指摘されてい る 13,14). 今回，ハムストリングスの伸張を目的とした 介入を行っていないことから, 腰背部筋の伸張性と骨盤 前傾角度の増加がFFDの変化に関与したことが考えら れる. 測定項目の一つである椎体間距離の差において, 測定時期に主効果が認められたことから, 腰背部筋の伸 張性が高まり, FFD 測定時の体幹前屈角度が大きくなっ たことでFFD が増加したと推測された。しかし，立位 体前屈と腰部屈曲との相関は低いとの報告から ${ }^{15)}$, 骨 盤前傾角度の増加が FFDの増加に, より関与していた 可能性がある。 また，しゃがみこみ動作は，骨盤を前傾 位に保持することによって可能となることが示されてい る5). この骨盤前傾角度の増加は, しゃがみこみ動作時 に骨盤を前傾位に保持しやすくさせたと思われる。よっ て, 介入後, FFDが増加したことは, しゃがみこみ動 作を可能とさせた一因であると推測された。

しゃがみこみ動作が可能とならなかったことの原因と して，まず，しゃがみこみ動作時の身体重心位置が挙げ られた。先行研究では, 不可能者のしゃがみこみ動作時 の身体重心は, 可能者と比較して, 後方に位置していた としているが 16), 本研究でも同様のことが生じていたと 考えられる。姿勢を保持するためには，身体重心の床面 への投射点が，支持基底面内の安定性限界のなかに収 まっている必要があるといわれている ${ }^{17)}$. 介入後, 不可 能者は, しゃがみこみ動作時に股関節を十分屈曲させて 腹部と大腿部を接触させることができず，身体重心が後 方へ偏移していた可能性がある。そのため，身体重心位 置は安定性限界のなかにとどまらず，しゃがみこみ動作 が可能とならなかったと考えられた。次に，介入期間に ついてである. 先行研究によると, 健常大学生を対象に ハムストリングスに対するストレッチングを 4 週間行っ た結果，下肢伸展挙上角度がストレッチング開始直後は 急激に，その後は緩やかに増加し，ストレッチング期間 終了後は, 一定のレベルで維持されたと報告してい る ${ }^{18)}$. 今回は 1 週間の介入期間で, 可能者は 26 名中 12 名であったため, 介入期間を延長することで, さらに可 能者が増加することが期待される。 今後は, SGM およ びSERの長期的介入においてのストレッチング効果が, しゃがみこみ動作に与える影響について検討していくこ 
表 3 介入後の男女間でのしゃがみこみ動作の可否の分布

\begin{tabular}{lccc}
\hline & 可能者数 $(\%)$ & 不可能者数 (\%) & $\mathrm{p}$ 值 \\
\hline 男性 & $9(52.9)$ & $8(47.1)$ & 0.340 \\
女性 & $3(33.3)$ & $6(66.7)$ & \\
\hline
\end{tabular}

男性の可能者 (SGM 群 2 名, SER 群 7 名), 女性の可能者 (SGM 群 1 名, SER 群 2 名).

とが必要であると思われる。また，回内足を有する人の しゃがみこみ動作では，しゃがみこみ動作時の股関節屈 曲角度が有意に減少するとされている ${ }^{19)}$. 個々の症例の 身体的要因も，しゃがみこみ動作が可能とならなかった 原因の一つである可能性が考えられる。このことから, しゃがみこみ動作時の股関節屈曲角度とその他の身体的 要因との関連についての将来的な調査も要する.

表 3 のように男女間の比較では，可能者数に有意な差 は認められなかった。しゃがみこみ動作の可否について 男女間で比較した先行研究では, 平成 27 年度から平成 29 年度に小中学生 219 名を対象に行われた運動器検診 で，男性に比べて女性の方が可能者は有意に多かったと している ${ }^{20)}$ ，一方で，大学生の身体柔軟性に性差は認 められないことが示されている21)。このことから，小 中学生とは身体組成が異なる大学生では，しゃがみこみ 動作の可否に有意な性差は認められなかったと考えられ た。しかしながら, 可能者の内訳は, 男性 (SGM 群 2 名, SER 群 7 名), 女性 (SGM 群 1 名, SER 群 2 名) とも にSER 群の可能者が多かった。 したがって, 性別にか かわらず，ストレッチングの違いがしゃがみこみ動作の 可否に少なからず影響を及ぼしている可能性があり, SER はSGM と比較して, しゃがみこみ動作の獲得に高 いストレッチング効果が期待できることが示唆された.

本研究によって, 股関節屈曲可動域を増加させるス卜 レッチングが, しゃがみこみ動作を可能にする効果が確 認できた。また，しゃがみこみ動作の獲得には，大殿筋 よりも股関節外旋笳群へのストレッチング介入が有用で ある可能性が考えられた。

本研究の限界について, しゃがみこみ動作時の評価と して関節角度を評価したが, 身体重心の偏移については 確認できていない. したがって，ストレッチング前後で 身体重心位置の変化をとらえることは，ストレッチング の効果としゃがみこみ動作の可否との関連を明らかにす るうえで必要な課題であると考える。また, 介入期間が 短期間であったことが挙げられる。今回は 1 週間の介入 期間を設け，26名中 12 名が可能者となった。しかし， 不可能者のなかでも, あとわずかで可能者となる見込み のある者も確認されたため, 介入期間を延長し, 引き続 き検討を重ねたい，さらに，男女間にどのような差があ るかについては, 今後, 身体組成やスポーツ歴などの観
点から男女間での比較を行い, 将来的な運動器症候群の 予防の一助としていきたい

利益相反 すべての著者は，開示すべき利益相反はない.

\section{引用文献}

1) 高橋敏明, 内尾祐司, 武藤芳照: 小览の運動器一運動器検 診の概念と目的一. Jpn J Rehabil Med, 2018, 55: 4-8.

2) 帖佐悦男: 学童期運動器検診とその動向. Jpn J Rehabil Med, 2018, 55: 9-13.

3) 川井謙太朗, 舟崎裕記, 林 大輝 - 他 : 野球, サッカー選 手におけるしゃがみこみ動作，正座の可否と下肢障害発生 との関連性について。理学療法科学, 2015, 30: 783-786.

4) 菅原真由美，杉田 聡，島田達生：女性のしゃがみ姿勢と 下肢関節可動域との関連. 形態・機能, 2005, 3: 43-49.

5) 景山 剛, 渡會公治：足関節背屈可動域抢よび骨盤可動性 がしゃがみこみ動作に及ぼす影響について。日本臨床スポー ツ医学会誌, 2016, 24: 213-218.

6) Kapandji IA: 関節の生理学 II, 原著第 5 版. 萩島秀男·他 (訳), 医歯薬出版, 東京, 1988, pp44-62.

7) McGovern RP, Kivlan BR, Martin RL: Length change of the short external rotators of the hip in common stretch positions: a cadaveric study. Int J Sports Phys Ther, 2017, 12: 10681077.

8) Bandy WD, Irion JM, Briggler M: The effect of static stretch and dynamic range of motion training on the flexibility of the hamstring muscles. J Orthop Sports Phys Ther, 1998, 27: 295300.

9) 日本整形外科学会, 日本リハビリテーション医学会評価基 準委員会:関節可動域表示ならびに測定法.リハビリテーショ ン医学, 1995, 32: 207-217.

10) 青木隆明：運動療法のための機能解剖学的触診技術一下 肢・体幹, 改訂第2版. メジカルビュー社, 東京, 2012, pp166-167.

11) 佐藤香緒里, 吉尾雅春, 宮本重範・他: 健常人に扔ける股 関節外旋筋群が股関節屈曲に及ほす影響. 理学療法科学, 2008, 23: 323-328.

12) Kapandji AI : カラー版 カパンジー機能解剖学 III下 肢, 原著第6版. 塩田悦二 (訳), 医歯薬出版, 東京, 2010, pp2-65.

13) 相原一貴, 小野武也, 石倉英樹 - 他：睡眠前後での指床間 距離の比較.ヘルスプロモーション理学療法研究, 2016, 6: 41-44.

14）野島恵理子, 佐々木 誠：他動的股関節内旋外旋運動が指 床間距離に及ぼす影響. 理学療法科学, 2005, 20: 187-190.

15) Kippers V, Parker AW: Toe-touch test. A measure of its validity. Phys Ther, 1987, 67: 1680-1684.

16）山崎祐司, 宮崎登美子, 井口由香利 - 他 : 足関節背屈可 動域としゃがみ込み動作の関係. 理学療法科学, 2010, 25: 209-212.

17) 望月 久: バランス能力測定法としての直立検査. 理学療 法一臨床 · 研究 · 教育, 2008, 15: 2-8.

18) 進藤伸一:「他動的伸張法」のトレーニング条件 (強さの条件) に関する基礎的研究. 秋田県理学療法士会誌, 1991, 1: 1419. 
19) Lee JD, Koh DH, Kim K: The kinematics of the lower leg in the sagittal plane during downward squatting in persons with pronated feet. J Phys Ther Sci, 2015, 27: 285-287.

20) 大高麻衣子, 平元 泉, 皆川洋至・他：小中学生のスポー ツ検診の取り組み一運動器障害と柔軟性の評価一。秋田大
学保健学専攻紀要, 2017, 25: 45-53.

21) 古後晴基, 村田 潤, 東登志夫：身体柔軟性と関節弛緩性 に打ける性差および関係性.ヘルスプロモーション理学療 法研究, 2015, 4: 189-193. 